DOI https://doi.org/10.36059/978-966-397-197-1/111-128

\title{
THE THEATER CONCEPT IN MODERN CULTURAL SPACE
}

\section{Ishchenko Yevhenii}

\section{INTRODUCTION}

From the first steps, humanity perceives the space in terms of their vital interests as forms of being, appealing to the perception, experiences, comprehension of the practice of each individual. Historically, the image of space has evolved at the same time as the formation of culture, which is why this category is the most important characteristic of being human ${ }^{1}$.

At all times, the theater was perceived as the most democratic, open to the society at large and accessible to the lower classes, a form of art unlike literature, which has an "elitist" character and required a higher level of development of intellectual abilities in humans. However, theatre in the minds of speakers of different languages is not only a theatre in the narrow sense of the word but also thought in a wide field of cultural, sociological, political, philosophical and art knowledge and is a rather contradictory concept that needs broad interpretation. ${ }^{2}{ }^{3}$.

Domestic and ceremonial entertainment, folk spectacles played a huge role in the development of the cultural polysystem in general and the theatre in particular. Not only did they make a huge contribution to the development of the theatre, but they also served as a basis for the

${ }^{1}$ Orlova E. V. (2009). Fenomen teatralnogo prostranstva: kulturfilosofskii analiz [The phenomenon of theatrical space: cultural philosophical analysis]. Izvestiia Saratovskogo universiteta. Seriia Filosofiia. Psikhologiia. Pedagogika, vol. 9, no. 3, p. 37.

${ }^{2}$ Kalinina S. A. (2011). Leksiko-frazeologicheskaia reprezentatciia kontcepta "Teatr" v russkoi i angliiskoi lingvokulturakh [Lexical and phraseological representation of the concept of "Theater" in Russian and English linguistic cultures]. Teoriia i praktika obshchestvennogo razvitiia, no 8, p. 374.

3 Adrianova T. O. (2014). Teatr kak sotciokulturnyi fenomen [Theater as a sociocultural phenomenon]. Vestnik Orenburgskogo gosudarstvennogo universiteta, no. 168 , pp. $82-85$. 
skill of future performers ${ }^{4}$. At the same time, the process of preparing the carriers of the cultural polysystem - spectators to understand the theatrical action as a mechanism of self-identification of the Self, the Other and the culture as a whole, in relation to which it became form and content at the same time, began. On the one hand, they exist within a culture relevant to themselves, stratified by its norms; on the other, they are expressions of culture, in fact, a culture that is determined by a certain discursive act.

In the philosophical, cultural, linguistic and other scientific fields there is a strong interest in understanding the concept of theatre. Extrapolation of the philosophical concept of theatre into the science of theatre initiates the development of theatre theory at the modern scientific level. Different levels of theatre concept are manifested in their entirety through the prism of the philosophical tradition, in particular, of aesthetic knowledge and the study of artistic tradition aimed at the understanding theatre as $\operatorname{such}^{5}$.

At the same time, the conceptualization of the concept is inherently integrative, because it is impossible to determine where the realm of cultural studies, sociology, art studies and so on ends.

The purpose of the article is to identify the concept of theatre and to determine its role in theatrical studies on the basis of the analysis of theoretical and practical material of the theatre arts.

A number of authors have been involved in the research of outlined issues, in particular, S. O. Arutiunov, M. M. Bakhtin, Yu. V. Bromlei, M. M. Hromyko, O. Ya. Hurevych， I. O. Yedoshyna， M. M. Zabylin, L. Ye. Kalmykova, V. V. Kolesov, D. S. Likhachov, M. O. Nekrasova, O. F. Nekrylova, O. M. Panchenko, V. Ya. Propp, O. M. Pypin, Yu. S. Stepanov, O. S. Khomiakov, M. O. Khrenova and others. Theater, its forms and social functions were investigated by T. M. Akimova, O. I. Biletskyi， P. G. Bogatyrov， I. M. Veletska， V. M. Vsevolodskyi-

${ }^{4}$ Batnasangiin S. (2009). Religiozno-istoricheskie nachala mongolskogo teatra [Religious and historical beginnings of the Mongolian theater]. Vestnik Tomskogo gosudarstvennogo universiteta, no. 320, p. 75 .

5 Azeeva I. V. (2008). Kontcept teatra i traditciia filosofskogo znaniia ( $\mathrm{k}$ probleme formirovaniia teorii teatra $\mathrm{v} X X$ veke) [The concept of the theater and the tradition of philosophical knowledge (on the problem of the formation of the theory of theater in the twentieth century)]. Izvestiia Rossiiskogo gosudarstvennogo pedagogicheskogo universiteta imeni A. I. Gertcena, no 11, p. 85. 
Hernhross, V. E. Husev, L. M. Ivlieva, V. D. Kuzmin, N. I. Savushkin, O. F. Nekrylova and others.

\section{The Scientific Conception of Theater and its Concept: \\ Characteristics, Features, Understanding}

The human activity in the development and processing of the outside world directly depends on person's perceiving spatial aspects, which is represented in forms of culture, one of which is language as a sign system. At the same time, there is a projection in the forms of cultural being, one of which is theatre as a certain medium for meaningful living. Thus, the spatial predetermination of human activity as social communication is of particular importance in theatrical creativity. Since ancient times, people have tried to learn, realize and expand their living space through play: wearing ritual masks (and the theatre is known to emerge during the gradual secularization of ceremonies and rituals), everyone could "tame" the incomprehensible, and therefore hostile reality ${ }^{6}$, adaptated it themselves, and thus "tamed".

The understanding of theatrical space as a theatrical culture has emerged rather than within the limits of theatrical, art or cultural studies, but within the limits of criticism and journalism. Often in critical articles about theatre, the term "theatre space" is used to mean the conditional totality of all phenomena in theatrical life: a series of performances, tours, performances by theatre figures, critics, conferences, educational institutions, etc.?

Our position is that the scientific definition of theatre is not identical to its concept. This is due to the fact that the basis of the concept is a category of meaning, that is, the concept involves reference to the theatre as its category. The scientific concept views theatre as a form of art, the essence of which is the artistic reflection of life through dramatic action, which is usually unfolded in front of the viewer. Not identical, the scientific concept of theatre and its concept have both a common part and separate components. For example, such an aspect of theatre art as a genre will belong to both the concept and the concept. The significance

${ }^{6}$ Orlova E. V. (2009). Fenomen teatralnogo prostranstva: kulturfilosofskii analiz [The phenomenon of theatrical space: cultural philosophical analysis]. Izvestiia Saratovskogo universiteta. Seriia Filosofiia. Psikhologiia. Pedagogika, vol. 9, no. 3, p. 37.

${ }^{7}$ Vozgrivtceva K. I. (2005). Teatralnoe prostranstvo: kulturologicheskii aspekt. Izvestiia Uralskogo gosudarstvennogo universiteta, no. 35, p. 58. 
of the concept is that it has something that cannot be inherent in a concept that deals with formative characteristics, namely, meaning. Thus, conceptualization in the cultural space is the sense-distinguishing boundary of theatrical research aimed at internalizing the purely artistic representation of the phenomenon of theatre into the paradigm of integrated and complex research.

In the process of analyzing the theatrical forms' origin, we naturally observe their indivisibility, unity with the play (playing with personal $I$, playing $I$ with another, playing the Other, according to current discursive practices, with culture, and through it - with myself, etc.). Indicative in this context is the religious mystery of the Tsam, which was spread in Tibet and later became popular in Mongolia. In essence, this is an esoteric religious rite, a mystery that aims not only to enlighten the audience, to remind them of the transience of their being but also to enter into a certain mystical union with the world, with a further doubling of joy and happiness ${ }^{8}$.

The above proves that theatrical art cannot develop beyond historical time and space, that it is discursive by its very nature, being represented as a simulation of ontological reality, it captures the axiological significance of its phenomena. The latter can be explained by the fact that the theatrical life is unfolding within the limits of socio-historical evolution. Theatre is always an expression of the thoughts, the atmosphere of the world public, progressive ideas presented in the artistic version, which, however, do not lose their significance or, on the contrary, lose: to give them public appreciation. Theatrical processing of the accumulated social experience, its transformation into the object of aesthetic, artistic, creative reflection takes place within certain spatial limits, which, in turn, produces the presence of spatial characteristics in it ${ }^{9}$.

On the example of the aforementioned, it clearly shows the cultural conditionality of the theatrical action, its discursiveness. In performing this performance, the actor-lama represented the leading Buddhist philosophical and religious principles. Thus, the content of culture was

${ }^{8}$ Batnasangiin S. (2009). Religiozno-istoricheskie nachala mongolskogo teatra [Religious and historical beginnings of the Mongolian theater]. Vestnik Tomskogo gosudarstvennogo universiteta, no. 320, p.72.

${ }^{9}$ Orlova E. V. (2009). Fenomen teatralnogo prostranstva: kulturfilosofskii analiz [The phenomenon of theatrical space: cultural philosophical analysis]. Izvestiia Saratovskogo universiteta. Seriia Filosofiia. Psikhologiia. Pedagogika, vol. 9, no. 3, p. 37. 
actualized in its forms: through the complex language of plastic, which, in turn, was its (culture) element. It is natural that the performer of such a performance needed to have strong, trained memory and body in order to study the numerical movements in the performance, which could last from one to seven days ${ }^{10}$. Thus, one can speak of certain originality, the specificity of the aforementioned theatrical space: being the space of creative development of reality, it can be attributed to the phenomena of culture and enter into the cultural space, which is formed through the creative activity of individuals aimed at transforming the natural world.

The peculiarity of cultural space is the granting of its temporal, spatial extent and axiological grounds. All this determines the axiological relation to the space-time aspects of being culture. At the same time, space and time are in unbroken unity, and objective spacetime relations exist as structured, multilevel integrity, as contradictory unity of different sides of being. At the same time, theatrical space as a kind of cultural space has also all its characteristics and simultaneously has a specificity that represents the ambiguity of axiological bases, which are characterized by temporal length and actual spatial boundaries.

Thus, the main feature of the values of the theatrical space is their contemporaneity, situational awareness: they are born and die with the performance and in tomorrow's presentation may not be repeated. Therefore, values in the theatre have nothing to do with the theatre itself (perceptions, photos, reviews, and so on). Even a taped performance ceases to be a theatre that exists in direct, live performance. The next performance may have different meanings, and make other accents. This allows the theatre-producing values to be positioned as preserving the atmosphere of uniqueness this evening, both for the viewer and for the people who create that atmosphere. Feeling of the uniqueness of the moment, the artistic event gives the theatrical effect ephemeral values and is a distinctive feature of the exclusively theatrical space ${ }^{11}$.

Thus, the "work" of the theatre concept is essentially based on the understanding of theatre as a universe, its explanation, interpretation.

${ }^{10}$ Batnasangiin S. (2009). Religiozno-istoricheskie nachala mongolskogo teatra [Religious and historical beginnings of the Mongolian theater]. Vestnik Tomskogo gosudarstvennogo universiteta, no. 320, pp. 73-75.

${ }^{11}$ Orlova E. V. (2009). Fenomen teatralnogo prostranstva: kulturfilosofskii analiz [The phenomenon of theatrical space: cultural philosophical analysis]. Izvestiia Saratovskogo universiteta. Seriia Filosofiia. Psikhologiia. Pedagogika, vol. 9, no. 3, p. 37. 
The concept of theatre, having integrity, is a vision of the theatre as such in its entirety, which allows us to speak about a certain ontological essence of its concept, the simulacrum, which is expressed in the desire to comprehend the existential existence of the theatre. By asserting the ontological fullness of the theatre concept, we also discover its substantive essence as a coherent system of meanings of theatre as such $^{12}$.

Spatial models, representations of theatrical space, have a multilayered structure and are a set of fundamental features (length, interruption / continuity, finiteness / infinity, dimension, and so on). It is these peculiarities that lead to the notion of a border that can be applied to theatrical space since its dialogical nature tends to be borderline. Theatrical art is on the border of all arts, all kinds of cultural space ${ }^{13}$. In particular, being a compound mental complex, the concept of theatre includes, in addition to its main content (the meaning of theatre as a universe), a number of components, for example, the national-cultural component of the concept of theatre (the meaning of the theatre functioning in a certain cultural environment), social (meaning the social function of the theatre), the individual-personal (subjective understanding of the theatre meaning of a particular personality) and other ${ }^{14}$.

It is significant in this respect that the spatial structure of any cultural phenomenon in the scientific literature is determined by qualitative and quantitative differences, so the first feature in which the concept of "theatre space" is separated from "theatrical space" is a quantitative, scale component. The theatre space is closed in one theatre, it is more local, static. Taking into account the division of theatrical space into the stage and the auditorium, the space of the theatre is the "stage". It absorbs everything that is inside - enters into the theatrical premises

12 Azeeva I. V. (2008). Kontcept teatra i traditciia filosofskogo znaniia ( $\mathrm{k}$ probleme formirovaniia teorii teatra $\mathrm{v} \mathrm{XX}$ veke) [The concept of the theater and the tradition of philosophical knowledge (on the problem of the formation of the theory of theater in the twentieth century)]. Izvestiia Rossiiskogo gosudarstvennogo pedagogicheskogo universiteta imeni A. I. Gertcena, no 11, p. 87.

${ }^{13}$ Orlova E. V. (2009). Fenomen teatralnogo prostranstva: kulturfilosofskii analiz [The phenomenon of theatrical space: cultural philosophical analysis]. Izvestiia Saratovskogo universiteta. Seriia Filosofiia. Psikhologiia. Pedagogika, vol. 9, no. 3, p. 37.

14 Azeeva I. V. (2008). Kontcept teatra i traditciia filosofskogo znaniia ( $\mathrm{k}$ probleme formirovaniia teorii teatra $\mathrm{v} X X$ veke) [The concept of the theater and the tradition of philosophical knowledge (on the problem of the formation of the theory of theater in the twentieth century)]. Izvestiia Rossiiskogo gosudarstvennogo pedagogicheskogo universiteta imeni A. I. Gertcena, no 11, p. 87. 
(from the creative part of the troupe to the prop, costume wprkshops and their workers, dressing rooms, etc.), and intangible substances - the relations of actors and director, the theatrical climate, the employment of actors, their relationships, the recharge of the troupe, all the theatrical rearrangements, scandals and so on. This includes not only the stage but also all the inhabited indoor theatre premises. It is a turn of the theatre life that people who do not belong to it do not see. The visible part of this space is the stage, the hall, the auditorium ${ }^{15}$.

It is generally accepted to represent the concept structure in the form of a circle consisting of a nucleus and a periphery. The concept of theatre also does not resist such a generalized-structural vision, in the centre of which is the basic concept, which is enshrined in vocabulary articles, and the periphery grows associative and other meanings, which are defined by the above components. Since the concept is intended to refer to the theatre as a category of meaning, it is natural to link the concept of theatre and the idea of theatre. The abstractness and discursiveness of the concept are developing thanks to the idea that, as a result of human perception of the theatre, it deploys the concept into a living theatrical organism $^{16}$.

At the same time, in the theatrical space, there is a dialogue with other types of cultural space, the culture itself, as well as all spheres that are not included in the structure of the cultural space. Communication here is widespread and has a wider spread. Theatrical space is open for mutual enrichment and interaction with other kinds of being. The space of the theatre is more closed in nature, it is static, closed in itself and carries only the characteristics of the theatre. Dialogue in the theatre space unfolds at the level of communication within it, but one space cannot exist without the other: a dialogue between theatre space and

15 Orlova E. V. (2009). Fenomen teatralnogo prostranstva: kulturfilosofskii analiz [The phenomenon of theatrical space: cultural philosophical analysis]. Izvestiia Saratovskogo universiteta. Seriia Filosofiia. Psikhologiia. Pedagogika, vol. 9, no. 3, p. 39.

16 Azeeva I. V. (2008). Kontcept teatra i traditciia filosofskogo znaniia (k probleme formirovaniia teorii teatra $\mathrm{v} X X$ veke) [The concept of the theater and the tradition of philosophical knowledge (on the problem of the formation of the theory of theater in the twentieth century)]. Izvestiia Rossiiskogo gosudarstvennogo pedagogicheskogo universiteta imeni A. I. Gertcena, no 11, pp. 87-88. 
theatrical space is as necessary as the dialogue between the stage and the auditorium $^{17}$.

The integration of scientific knowledge about theatre requires its conceptualization, which is done by constructing a theatre concept. The concept of theatre as a scientific definition is rarely used in the science of theatre. The concept of theatre in scientific knowledge is in some way an orderly bunch of theatre "meanings" as a universe. The conceptualization in the space of the science of theatre is more represented in the territory of theatre theory, which, as already noted, is the least developed scientific layer of theatrical science. This is largely explained by the weak demand for concept and conceptualism in the science of theatre. Appealing to the concept in theatre studies is often perceived as something depleting the theatre, as one that refines the artistic meanings ${ }^{18}$.

From a cultural point of view, theatrical space is a coherent ontological category that determines the place of theatre's existence in cultural space, so theatre space and theatrical space cannot exist without each other. Expanding the boundaries of the theatre space, compacting its semantic layer also leads to a change in the state of the theatre space, its qualitative characteristics and vice versa. However, neither one nor the other space exists without the creative participation of man as a subject of the theatrical process ${ }^{19}$. Such a distinction is, in our opinion, connected with the development of scientific knowledge of theatre, which is engaged in the complex of theatrical sciences, which are integrated into a voluminous independent scientific discipline (institution) of "theatre studies", which studies the theory and history of theatre. Theatrical Studies, which is one of the "young" art disciplines, its final formation as an independent scientific institution occurred in the

17 Orlova E. V. (2009). Fenomen teatralnogo prostranstva: kulturfilosofskii analiz [The phenomenon of theatrical space: cultural philosophical analysis]. Izvestiia Saratovskogo universiteta. Seriia Filosofiia. Psikhologiia. Pedagogika, vol. 9, no. 3, p. 39.

18 Azeeva I. V. (2008). Kontcept teatra i traditciia filosofskogo znaniia ( $\mathrm{k}$ probleme formirovaniia teorii teatra $\mathrm{v} X X$ veke) [The concept of the theater and the tradition of philosophical knowledge (on the problem of the formation of the theory of theater in the twentieth century)]. Izvestiia Rossiiskogo gosudarstvennogo pedagogicheskogo universiteta imeni A. I. Gertcena, no 11, p. 87.

${ }^{19}$ Orlova E. V. (2009). Fenomen teatralnogo prostranstva: kulturfilosofskii analiz [The phenomenon of theatrical space: cultural philosophical analysis]. Izvestiia Saratovskogo universiteta. Seriia Filosofiia. Psikhologiia. Pedagogika, vol. 9, no. 3, p. 40. 
twentieth century. This statement does not deny the sufficiently deep tradition of the science of theatre ${ }^{20}$.

\section{The Philosophical Discourse in Theater Science}

Characteristic of theatrical studies of the XX century there was a desire for philosophical conceptualization. In our view, the philosophy of art examines the links between philosophy and art through their focus on cognition, reflection, community, and at the same time individuality. In the work "The Source of Artistic Creation", M. Heidegger referred to art as the source of his own ability to think, as a form of truth. Genesis is hidden, but there are topos through which Genesis presents itself. Art (not philosophy) draws us to Genesis: the work of art is the creation. The world has never been a subject that we can see. The world is so meaningless that it has power over us. In the classical scheme of the relationship between philosophy and art, the latter has no category of thinking, thought is introduced into art, it is, because of its own specificity, the mediator between reality and philosophy, offering a special form of existence of truth. Heidegger pointed to art as a condition and round form of the deployment of thought about being. Truth in philosophy requires the basics, without the acquisition of which it is not true. But the art was originally located in the space of truth, otherwise, it cannot exist. The creative process is the deployment of truth in art. The philosophy of the theatre reveals itself in thinking about the nature of theatre regarding Existence. It is a collection of experiences, the pathos that acts directly on the human soul. From here on the theatrical stage, there is an opportunity to change psychological attitudes towards such moral and ethical categories as revenge, envy, jealousy and more. From this perspective, Shakespeare's works, in particular, are read in a new way. Shakespeare has ventured to transform the canon of a revenge tragedy through religious and ethical considerations rather than through theatrical theory and aesthetics. Why did Hamlet ultimately abandon his revenge? Where were the origins of his inaction? This "illness of character or will" was nothing but faith in God. It was a reluctance to

20 Azeeva I. V. (2008). Kontcept teatra i traditciia filosofskogo znaniia (k probleme formirovaniia teorii teatra $\mathrm{v} X X$ veke) [The concept of the theater and the tradition of philosophical knowledge (on the problem of the formation of the theory of theater in the twentieth century)]. Izvestiia Rossiiskogo gosudarstvennogo pedagogicheskogo universiteta imeni A. I. Gertcena, no 11, p. 86. 
break the commandments. There was a doubt that there was something in earthly life for which a person could lose his own soul.

Shakespeare reveals to us Hamlet as a man who is both in boundary dynamics and in statics. A number of external circumstances instantly put Hamlet in a situation of mistrust. At the same time, he has a rare ability to distinguish between good and evil. Shakespeare's character at first refuses to mix God with the devil, seeking support from both, emphasizing the need to distinguish between the higher powers that drive the actions of the earthly man. Honesty is the second core of Hamlet's character after faith. It can even be argued that it is pathologically honest. Hamlet is absolutely incapable of being reincarnated and hypocritical, so he chooses the truth of the madman. Shakespeare contrasts the image of Machiavellian (which became popular during the Elizabethan drama) the image of Claudius, characterized by the pangs of conscience and fear of punishment. Hamlet enters the play by choosing "to be" instead of Machiavellian's "give up".

Shakespeare has also a multifaceted structure of revenge. The action of Shakespeare's tragedy builds on a series of internal parallel lines, each of which incorporates a potential plot of revenge for the murdered father: the Hamlet Line, the Laertes Line, the Fortinbras Line, and, finally, the Ophelia Line. Through these lines and their juxtaposition, the playwright realizes his plan.

Moreover, the play contains a number of other plot options for revenge: the mention of the murder of Pyrom Priam (in the speech of the First Actor), the murder of Gonzaga, several references to the first murderer on earth - the murderer of his brother - Cain, and others. All this is nothing but revenge plot options.

"Hamlet" is a tragedy that examines the paradigm of revenge itself and in this sense is similar in genre to the problematic play.

The Ophelia line is too important. Beloved Hamlet's story and her strange and wonderful death is an alternative story of non-revenge in the tragedy. True tears instead of blood, a prayer for the salvation of all the souls of Christ is forgiveness, and therefore, approaching to grace. And finally, after her burial, Hamlet himself will make a speech about giving up intentional evil.

In each of the prince's mentioned precedents of revenge, there are own ascending conditions, own climax and own end. The situation, the paradigm of revenge is constantly changing, painfully analyzed by Hamlet, consistent with his idea of the proper state of the world and man. 
The tragedy of Hamlet's situation throughout his work is due to the dualism of his perception of the world: the confusion and mistrust of the believing person. In these circumstances, the search for a hero of integrity is tragic.

In Shakespeare's tragedy, one can find inexhaustible layers of meanings. They are already embedded in the plot-archetype of a father and a son addressed by a playwright. In it, the father is the creator, the beginning, the example, the ideal, the sacrifice. He has a son - an image, a disciple, a potential avenger, and also a victim. But also the carrier of a new worldview, which creatively interprets his father's commandments, gives the world new directions.

Shakespeare transformed a purely theatrical space, more precisely, purged it from intentional evil. The key themes of the "Macbeth" tragedy are mainly identified in the first two scenes. This is a regular rule of Shakespeare to indicate clearly the main semantic vector in the exposition of the work clearly. Therefore, the reader's job becomes much more complicated than the viewer's. If actors, artists, and directors are to help orient the viewer properly, the reader should pay special attention to the first scenes of Shakespeare's plays.

The first scenes of "Macbeth" emphasize three themes that will later develop into the main action. The first is the idea that there is no boundary between good and evil.

Secondly, it is a topic of uncertainty about fate and thirdly, it is a topic of valour as an imperative. Thus, Macbeth appears in the first scenes as a model of charity, but the viewer knows that in his soul the decision has already been made to change, in the language of Aristotle, the "direction of will" and to direct his best qualities to the achievement of other goals.

Shakespeare's Macbeth, whose crime is not a matter of error, but the result of his own choice, does not quite meet the requirements of the tragic hero. How did Shakespeare imagine the process of transforming man into his own instrument?

Almost as modern researchers call this blurry of individuality. Lady Macbeth's philosophy of action captivates the viewer. Fear is not a crime, but a thwarting of his attempt to commit it as well as a fascination with N. Machiavelli's philosophy of action, despite its immorality. Loyalty to oneself makes a person weak. It is an opinion that stems from Machiavelli's doctrine of the need to change behaviour depending on the circumstances, not so much as "being" but as "giving up" to one or the other depending on the situation. From the point of view of 
Machiavelli's follower Lady Macbeth, stability, loyalty to nature is not good, but evil for a hero who works for a great cause. She chooses the first option from two imperatives "consistency in purpose" and "loyalty to oneself".

Machiavelli pays much attention in the pages of his own treatise to reflect on the different tactics of those who go to power and who have already received this power. If one goal (the achievement of power) justifies a certain course of action, then another goal (the retention of power) provides a completely different tactic, doing harm to what has previously benefited.

"Things bad begun make strong themselves by ill" - "evil spreads evil" or "evil generates evil". This is how one can translate Shakespear's words, which have a deep philosophical basis for the arrangement of human nature and the laws of the human psyche. And all this takes place in a theatrical space in which Shakespeare created new meanings, experimented, modelled human nature and life situations.

Shakespeare theater was a medieval theatre. Shakespeare interpreted Machiavelli's teaching not as the reverse of the ideals of the Renaissance, but as their cruel replacement. The subject of change and unclean substitution in the medieval mind was the devil. This explains the logic behind identifying Machiavelli with him in English theatre and public consciousness. In fact, the literary-theatrical Anti-Machiavelli was created in England. Shakespeare's dramatic creativity is central to this discourse.

Shakespeare's inability to rely on individual prowess, the superiority of power over word and law, the notion of religion and belief as a means by which humankind could be kept in check was unacceptable.

Machiavelli, unlike Shakespeare, does not take into account the presence of God in human nature. Human cohabitation for Machiavelli is born of individual strength, arrogance, and the like. Instead, for Shakespeare, man is a divine creation of "all in all". Therefore, Hamlet forgives people's minor shortcomings.

Machiavelli has absolutely no perception of natural law and the idea of God's accomplishment. Shakespeare, by contrast, shares the traditional Christian view of the inability to know the ways of the Most High.

Machiavelli believed that it was more useful to appear kind, reliable, courageous and not to be them. Shakespeare, on the other hand, did not perceive veil and hypocrisy. 
Politics that overpowered conscience, wisdom devoid of sincerity, valor that destroyed ambition - all these things were condemned by Shakespeare, because they destroy the perfect picture of the world.

In 1608, the theatrical character of the Machiavellian cast became established in the English performing arts. Moreover, one can speak of the isolation of a particular psychological type of "political person".

The essence of Shakespeare's objections was clear to the viewer of varying degrees of education. At the heart of this answer are the notion of individual morality, moral law and the inevitability of punishment. These ideas relate to the tradition of medieval folk piety, which focuses on popular Christian commandments.

Having also covered the political component in the study of the concept of theatre and theatrical space, we have addressed the following questions: the particular features of Shakespeare's understanding of Machiavelli's teachings, the forms of the presence of Machiavelli's image, and the theme of Machiavellianism in his work and in the entirety of the Elizabethan culture; the reasons for the predominantly polemical perception of Shakespeare's Machiavelli doctrine, from which positions there was controversy, what is the essence of Shakespeare Machiavelli's objections; the conflict of ideas of Shakespeare and Machiavelli about the nature of the earth's helmsman and the legitimacy of the problem of "perfect helmsman" in the work of Shakespeare.

Shakespeare, unlike Machiavelli, stood for the Great Divine Order. Shakespeare's theatre was still closely associated with medieval religious theatre. However, for Shakespeare, there was already a secularization of consciousness. It was important that it was the motive of prayer in some of Shakespeare's plays, which points to the sacred role of theatrical space and the additional lever in the exchange of processes of consciousness. The monologue "To be or not to be" is a continuation of Hamlet's dialogue with his own soul. To endure the suffering of the earthly life or to rebel against it, that is, to die, to fall asleep? The philosophical component of the theatrical concept constantly appears in Shakespeare's plays.

The reflection of R. Barth's theatre is more intellectual in contrast to, say, the Russian theatrical tradition. Russian theatre looks like a holistic phenomenon, a kind of monolith. Theatre, in the interpretation of $\mathrm{R}$. Barth is absent in its isolation, the rejection of conventions. The ideal for Barth is an epic, rich in philosophical ideas, the B. Brecht theatre. Theatre does not reject rationality but represents rationality as a means of solving urgently important problems. In the modern world, the B. Brecht 
theatre embodies the functions of philosophy rather than philosophy itself. Brecht returns to the theatre the forgotten role of the forum.

According to one of the theatre reformers of the twentieth century, A. Artois, the theatre became too dependent on the word, on the text, on the play, which is interpreted exclusively verbally in the contemporary theatrical space. The theatre became literary. Instead, Arto believed, the theatre should lose its focus on the written word.

In our view, the philosophy of theatre is represented by the conception of the Russian philosopher and theatre theorist M. M. Yevreinov, who largely foresaw the idea of "theatricalization of life." The person has an instinct, which, despite his inexhaustible vitality, neither history, nor psychology, nor aesthetics has not been spoken about yet. It means the instinct of transformation, the instinct of opposing images that are arbitrarily created by man. Theatricality can be applied to different situations of life and revealed in all spheres of human life. Theatre is a detailed metaphor of the nature of human behaviour. Theatre in the narrow sense of the word (art) is regarded as a concentrated form of universal and general laws of being. Theatricality is another reality of life, irrespective of the laws of everyday life, with its real logic, with its morality and feelings. The origins of theatricality, according to Yevreinov, are hidden in the depths of all human culture and have their original, biological roots. Theatricality appears before the emergence of civilization and homo sapiens. In the article "Theater at Animals" the author finds examples of theatrical behaviour even in plants (imitation, mimicry), where the ability to "give up" is not a futile step, but a necessity in the process of survival.

"The Philosophy of Theater" is a unique creation of S. D. Krzhyzhanovskyi. The work traces the movement and development of the theatre. According to the author, a true philosophy of theatre is possible only if the theatre and everything else coincides, that is when there is nothing in the world that would not be a theatre in one or another of its modifications. Krzhyzhanovskyi reveals the similarity of Kantian philosophy and theatrical scenario (the scenario of the theatre life or its fate), which helps him to ask the question about the essence of theatre. After all, if you take the essence of the script and the "Critics of Pure Reason", they are surprisingly similar. I. Kant as a majestic figure of world culture is compared not only with the theatre in general but also with its most prominent representative Shakespeare. Theatre is a game of phenomena, a game of ghosts. The game of what does not exist in the real world, but at the same time, that brings us to the everyday level. All 
that plays out on stage is the fruit of our imagination, the play of ideas and meanings, but all this can not exist only in our head. The play of the actor gives the opportunity to invent and to think, it allows new meanings to be born in which the ontological content is ordered. The stage and the actor play are the models of real life.

Krzhyzhanovskyi's methodology has its own game - a game with the category of being. It comes from being, and as a result, there are three important mods for the analysis of the theatre concept: the history of the theatre can be represented as the birth of "theatre of being" (mystery), change it as "theatre of life-being" (tragedy), then "theatre of life" (drama). The stage is captivated by the strongest. Changing the theatrical language of contemporary theatre, Lehman considered the result not only of the aesthetic evolution of the theatre itself but also the result of the profound transformations that modern society and the human personality undergo. First, we are talking about the "Guttenberg era" crisis, which has been spoken about a lot lately. In the XXI century, the very nature of perception changed. Multifaceted one replaces linear and consistent understanding. The literary text, the book were dealt a serious blow. Slow reading, as well as thorough, heavyweight theatre, risks losing its status. The theatre is no longer a medium of communication. In the conditions of rapid technocratic development of civilization, "speed" and "superficiality" become factors that hinder the release of active energy of human imagination, which leads to the passive consumption of information and artistic images. And theatre and literature, which are predominantly iconic rather than illustrative, require focused and indepth perception. In addition, the sphere of culture is increasingly subject to the law of profitability. However, with the obvious conservatism caused by its very nature, theatre, nevertheless, is in a state of constant search and development. This is a prerequisite in order to maintain a place in society and to compete with technically sophisticated means of communication. At the same time, Lehmann acknowledges that not all theatrical forms of recent decades are in line with the post-dramatic paradigm. However, in the second half of the 1990s, an opposite tendency emerged, which, according to some experts, proved the most productive - a new realism. This is a depreciation of symbolic language in favour of the theatre, which, through self-reflection and self-reference, only realizes its own theatricality or largely refuses the language for the sake of performative theatre of physicality, new realism contrasts the rehabilitation of dramatic text, hero and action. "Post-dramatic theatre" 
and "new realism" are the two most important poles of modern European theatre now.

\section{CONCLUSIONS}

The cultural significance of the theatrical space's values has a dualorientation. Valuable grounds arise as a result of the theatrical process. They constitute both aesthetic and ethical, literary, political, and even material (scenery, props, costumes, and so on) values. Such versatility of localization leads to the opposition of "space of theatre" - "theatrical space". The theatre space has a more local character, less mobile, attached to a certain materialized theatrical space as the location of the theatre in the city space, life. Instead, theatrical space has broader boundaries, a wider spectrum of distribution, and theatrical space is a definition that includes all the features of the theatre, it is used when considering the variety of forms of existence of the theatre and it is related to the characteristic its concept.

Identifying the concept of theatre in the tradition of philosophical and actual theatrical knowledge, the analysis of this phenomenon allows us to confidently assert not only the presence of integrative use of philosophical discourse in theatre, but also the obvious perspective of concentration on the concept of theatre for the development of the science of theatre in general, and in general, for his theory and practice.

The above confirms the relevance and urgency of the study, whose purpose is to identify the presence of the concept of the theater on the basis of the analysis of theoretical and practical material of the theatrical art. It should be noted that in the process of deep appeal to the theatre as a category of meaning, it is important to seek to understand theatre as a concept in the scientific and artistic knowledge of previous eras, up to the time of pre-scientific knowledge, which actualizes a number of ideas about theatre in mythology, religion, and language.

In order to grasp theatrical space, one must become a "man of the theatre", which will become one of the defining phenomena of the professional and creative vocation of a young man, who decides to devote his life to the art of theatre, theatrical professional activity. Therefore, the formation of the foundations of the phenomenon of "theatre man" is one of the primary tasks of the theatre school, which deals with the education of modern creative personality. 


\section{SUMMARY}

The purpose of the article is to identify the concept of theatre and to determine its role in theatrical studies on the basis of the theoretical and practical material's analysis of the theatre arts. The methodology and theoretical basis of the study are determined by the purpose of the article, the specifics of the subject and object. The main theoretical basis of the study were works on the theory, philosophy, history and methodology of the culture of such cultural scientists and philosophers as M. M. Bakhtin, V.S. Bibler, M. Ya. Danilevskyi, I. O. Ilin, M. S. Kahan and others The sociocultural approach made it possible to consider the concept of theatre as a multifaceted and multifaceted process. The systematic approach provided the opportunity to use in the study of a whole range of methods: comparative, biographical, cultural-historical, axiological, hermeneutic, chronological, semiotic, differentiation, typing, grouping and modelling method. The scientific novelty of the obtained results is comprehensive coverage of the concept of theatre. Scientific conclusions have been made regarding the nature, features and objectivity of the existence of this phenomenon in culture and the justification for the necessity and feasibility of its further study. Conclusions. Revealing the concept of theatre in the tradition of philosophical and actual theatrical knowledge, analysis of this phenomenon allow us to confidently assert not only the presence of integrative use of philosophical discourse in theatre but also the obvious perspective of concentrating on the concept of theatre in the development of science of theatre and especially for his theory and practice.

\section{REFERENCES}

1. Adrianova T. O. (2014). Teatr kak sotciokulturnyi fenomen [Theater as a sociocultural phenomenon]. Vestnik Orenburgskogo gosudarstvennogo universiteta, no. 168, pp. 82-85.

2. Azeeva I. V. (2008). Kontcept teatra i traditciia filosofskogo znaniia (k probleme formirovaniia teorii teatra $v \mathrm{XX}$ veke) [The concept of the theater and the tradition of philosophical knowledge (on the problem of the formation of the theory of theater in the twentieth century)]. Izvestiia Rossiiskogo gosudarstvennogo pedagogicheskogo universiteta imeni A. I. Gertcena, no 11, pp. 85-92.

3. Batnasangiin S. (2009). Religiozno-istoricheskie nachala mongolskogo teatra [Religious and historical beginnings of the Mongolian theater]. Vestnik Tomskogo gosudarstvennogo universiteta, no. 320 , pp. $72-75$. 
4. Diachenko R. (2017). Hotels and restaurants of Lviv in the context of hospitality : past and present. National Academy of Managerial Staff of Culture and Arts Herald, no. 2, pp. 41-45.

5. Kalinina S. A. (2011). Leksiko-frazeologicheskaia reprezentatciia kontcepta "Teatr" v russkoi i angliiskoi lingvokulturakh [Lexical and phraseological representation of the concept of "Theater" in Russian and English linguistic cultures]. Teoriia $i$ praktika obshchestvennogo razvitiia, no 8, pp. 374-377.

6. Nikitina O. N. (2016). Istoricheskaia dinamika iskusstva: muzyka $i$ teatr [The historical dynamics of art: music and theater]. Izhevsk: Udmurtskii universitet. (in Russian)

7. Orlova E. V. (2009). Fenomen teatralnogo prostranstva: kulturfilosofskii analiz [The phenomenon of theatrical space: cultural philosophical analysis]. Izvestiia Saratovskogo universiteta. Seriia Filosofiia. Psikhologiia. Pedagogika, vol. 9, no. 3, pp. 36-41.

8. Ovcharuk O. (2018). Transformation of human immediates in Post modern cultural practices. National Academy of Managerial Staff of Culture and Arts Herald, no. 4, pp. 12-16.

9. Vozgrivtceva K. I. (2005). Teatralnoe prostranstvo: kulturologicheskii aspekt. Izvestiia Uralskogo gosudarstvennogo universiteta, no. 35, pp. 57-63.

10. Yan I. (2017). Ukrainian music and drama theater in the context of the nation creation process of the last third of the XIX - beginning of XX century. National Academy of Managerial Staff of Culture and Arts Herald, no. 2, pp. 119-121.

\section{Information about the author:} Ishchenko Yevhenii, orcid.org/0000-0002-5701-7829 $\mathrm{PhD}$ in Philology Kyiv International University 49, Lvivska Str., Kyiv, 03179, Ukraine 